This is an Accepted Manuscript of the article "Ligtvoet I.J.G.C. (2018), Made in Nigeria. Duress and Upwardly Mobile Youth in the Biography of a Young Entrepreneur in Enugu, Conflict and Society. Advances in Research

4(1): 275-287." published by Berghan Journals and is available online: https://doi.org/10.3167/arcs.2018.040120

\title{
Made in Nigeria
}

Duress and Upwardly Mobile Youth in the Biography of a Young Entrepreneur in Enugu Inge Ligtvoet

Abstract: What does duress mean in the lives of those who are not by definition understood to be living in duress - namely, upwardly mobile young people in a relatively peaceful city in southeast Nigeria? In this article, I try to answer that question by presenting the life story of Azu, a young designer in Enugu who has made his way out of a poverty-stricken background through a relatively successful entrepreneurship. His biography, based on interviews and observations, and partially through a shared experience of constraint in Nigeria, serves as an example of duress in the lives of those who — by family, educational background, or career success — are considered "well-off" compared with most youths in the country. I argue that duress for these youths is informed by social expectations due to their acquired status as much as by the sociopolitical uncertainties that they have been confronted with throughout their lives.

Keywords: biography, duress, hardship, Nigeria, tactics, uncertainty, upwardly mobile youth

"I know the background I'm coming from, and I know who I want to be. There's a man inside me that is bigger than the frame you're seeing now."

- Azu, Enugu, 11 December $2014^{1}$

Azu (born in 1984) dreams about one day sewing the clothes of the president of Nigeria and becoming the richest man in the world so that he "can reach out to the people who have no livelihood" (interview, 11 December 2014). He is a self-taught designer of shoes and bags and 
manufactures his colorful products in his workshop on a school campus in Enugu, southeast Nigeria. Fame and money, he believes, would ultimately help him achieve his goal of impacting the lives of youth who, like him, have been constrained by their family background and by Nigeria's harsh socioeconomic context. His experience of living in persistent hardship in society has defined much of Azu's life course, the decisions he makes, and the aspirations he has for the future-including his dreams for the next generation of Nigerian youth. In this article based on his biography, I argue that Azu is living in duress (see de Bruijn and Both, this issue): he is navigating through life and following his aspirations, yet he is constrained by the internalized hardship of his youth and the invisible constraints of being a young, upwardly mobile man in Nigeria.

Duress is defined as the internalization of experiences of enduring hardship, and the actions taken as a consequence of this internalization (de Bruijn and Both, this issue). Rather than describing the external, often political, factors of hardship (such as war or oppression), duress refers to the embodiment of hardship by the people who live in it. In societies that experience long-term insecurity—war and violence, political oppression, poverty, corruption-it is relatively easy to understand how the experience of this duress constrains the agency of the most vulnerable citizens. But if duress is structural (see de Bruijn and Both, this issue), what does it mean for those living upwardly mobile or middle-class lives? How does it affect them? Focusing on Nigeria, I argue that, even though their experience with the absent state and corruption is different than for the most vulnerable people, young, upwardly mobile people in southeast Nigeria do live in duress. Despite the fact that they often have more resources (financial and social) available to them, their long-term experience with a failing, absent government and with corruption does indeed affect and even limit the space in which they can 
make choices and decisions.

Azu is a young, upwardly mobile man - made in Nigeria, made in duress, just like the shoes and bags that he proudly sells as locally manufactured products, as opposed to the "fake" Chinese products that can be found on most Nigerian markets. And just as the production of his shoes is often disrupted and delayed (because of, for example, corruption, lack of electricity), so too are Azu's decisions and actions often determined by living in duress. In this article, I discuss Azu's life trajectory by introducing part of his biography and his everyday reality of duress, and, as such, I aim to provide insight into what duress means for the lives and futures of upwardly mobile Nigerian youth like him. I argue that biographies, based on interviews and on information gathered through long-term, intimate interaction with people in duress, provide insight into the emic reality of duress and how it affects choices and decision-making. I will show that biographies can help us to gain a deeper understanding of the meaning of duress in less obviously affected layers of society, such as those of upwardly mobile and middle-class youth.

\section{A Biographical Approach}

In order to understand duress and the internalization of hardship and violence (de Bruijn and Both, this issue), one must comprehend in depth the life of those living in duress. This means listening to what they have to say-in interviews, in informal conversations - and observing their everyday praxis. It requires a certain understanding of sensitive aspects of life; these aspects can sometimes be understood only through the researcher's own experience of them in the field (Davies 2010: 3). Michael Jackson argues, "We do violence to the complexity of lived experience when we make analytical cuts between emotion and thought, or emotion, the senses, thought and action" (2010: 35). Ethnographies that aim to understand duress should include 
information about our relationship with our interlocutors, as "social life is lived at the interface of self and other" (1998: 35). In other words, within the context of a wider ethnography, the feelings of our interlocutors and of ourselves are a window to understanding what factors play a role in the duress of a society: whether it is exposure to violent conflict, or harshness of a less obvious impact such as ordinary social violence embedded in the particular history of an individual and/or society (Bouju and de Bruijn 2014). We must therefore make silences, gasps, anger, laughter, frustration, sadness, fear, worry, and so on integral parts of our observations, interviews, and ethnographies, and we should not avoid the interpretation of these out of a fear of being overtly subjective. However, as with any other data, we must be aware that absolute certainty is not the aim of an ethnography; the objective is to find relative, plausible answers to our questions, knowing fully well that we risk being wrong at times (Leavitt 1996: 532).

This article is based on ethnographic data I gathered in close interaction with Azu over a period of 11 months in Nigeria in 2014, and in three more years of digital interaction from 2014 to 2017. The quality of this long-term fieldwork is found not only in the interviews and field notes on record; the experiences of "being there" and following Azu's life and the lives of his friends and family on a long-term, everyday basis form knowledge that goes beyond what was said or done. It has allowed me to gain an understanding of Azu's fears, hopes, and dreams. Viewing these in relation to the constraints of his everyday life allows for an analysis of duress in his life, as an example of those in similar positions in Nigerian society. ${ }^{2}$

Understanding the choices and decision-making of youth in duress can only be gained by addressing our interlocutors' lived experiences, experiences that are shaped by their engagement with the past, present, and future (Svašek and Skrbiš 2007: 378). I have opted for a holistic approach, in which observations, informal conversations, and nonverbally expressed feelings and 
frustrations are as important as formal interviews, if not more so. Over the months, my relationship with Azu became one of friendship, in which I was more than just the researcher and he more than the interlocutor. I shared in his daily life as much as he shared in mine, and this built the mutual trust that I believe has allowed me to honestly include Azu's emotional reflections in his biography. Although I have, by no means whatsoever, experienced life in Nigeria the way Azu has, we would often be confronted by similar constraints in our work and everyday living. We were almost the same age, young and independent workers relying heavily on modern technology for work and our personal lives. The lack of infrastructure (e.g., electricity, water) and issues of corruption were limiting to us both. Azu would have to sandpaper his shoes manually when the electricity went off, while I would have to make notes on paper or resort to working in noisy fast-food restaurants with generators. Through our conversations (and silences) about these issues, I learned about the meaning of duress, not only conceptually but also phenomenologically, because I could feel to some extent what he was feeling. I argue that our shared experiences allow me to interpret, in Azu's biography, my observations and conversations during the time I spent working with him from an emotionally informed perspective while simultaneously being able, as an ethnographer, to understand it in the broader context of the research I conducted.

Biographies have "proven to be an excellent way of making theoretical sense of social phenomena" (Apitzsch and Siouti 2007: 3). They can help us disentangle emotions and the lived experience(s) of people and understand them in the context of hardship, whether this is in times of violent conflict or in long-term lingering insecurity and uncertainty. Azu's biography serves as an analytical tool to understand the choices of young Nigerians with regard to their position in society. Marjo Buitelaar describes agency as "the biographical choices that people make in order 
to lead 'a good life"' (2014: 31). Following her, biographies serve as an important tool for making sense of people's everyday praxis and should not be a mere "descriptive account of [a person's] course from birth, through adolescence, maturity, and old age, to death" (Barman 2010: 65).

In the context of this study, we cannot even attempt to grasp a full life cycle's history, since Azu has not yet reached an old age. The significance of the biography for the question at stake should be made fully clear. As we are seeking to gain an understanding of duress by addressing the experiences that youth have and the (un)conscious strategic choices they make to "prosper," significance should be found not only in what is narrated in interviews or said in informal conversations. A large part of the significance of biographies is found in the emotionality of choices made and the transitions gone through (often unconsciously). Not every biography follows the structure so often emphasized by researchers who conduct biographical narratives or life history interviews (Rosenthal 2004).

The lives of people in duress do not conform to a linear idea of becoming of age. I argue that we should instead look at specific biographical moments within the lives of informants that are crucial in their personal development. Jennifer Johnson-Hanks describes these moments as vital conjunctures: "moments when seemingly established futures are called into question and when actors are called on to manage durations of radical uncertainty ... navigated in reference to their horizons - the imaginable futures that are hoped for or feared" (2002: 878). A vital conjuncture implies a space and time of uncertainty, in which choices must be made for the course of the short- and/or long-term future - whether such choices are always consciously made or not. And although these choices are personal, the imagined futures are socially constructed, depending on social, cultural, political, and economic opportunities or "horizons." Therefore, 
biographies of these crucial decision-making moments, these vital conjunctures, of youth in southeast Nigeria not only provide insight into personal aspirations but also show the possibilities and limitations set by the country's context of insecurity. Social change can then be seen as the sum of the various individual itineraries of change (Johnson-Hanks 2002), and biographical analyses of these provide not only "the reconstruction of intentionality ... but the embeddedness of the biographical account in social macro structures" (Apitzsch and Siouti 2007: 7).

In the biography of Azu that follows, I will look at specific, crucial moments in his young life that determined his life course, often moments of radical change in terms of location, education, and work.

\section{Everyday Insecurity and Duress in Nigeria}

In early December 2014, I was traveling to Ibadan from my fieldwork home in Enugu, southeast Nigeria. I was going to visit friends and decided to buy some slippers from Azu as a gift for their children. I knew he would sign them with the name of his fashion label and "Made in Enugu," which I believed made the slippers an original gift. A few days before I was to travel, Azu asked me to pick up the shoes from his workshop early in the morning. He had to travel to Warri later that afternoon for a private teaching job with a middle-class couple that intended to start a similar fashion design business in Delta State. I arrived early in the morning and found Azu completely covered in dust, his face hidden behind a piece of cloth, and dark sunglasses protecting his eyes. He was busy sanding the soles of a large order of slippers with a sanding machine. I had already seen the sanding machine in his small workshop, a bright pink container on the campus market of IMT (Institute of Management and Technology, Enugu, Campus III), but he had never used it 
in my presence. On previous visits, I had only ever seen him sanding manually with sandpaper.

The large order of slippers, 70 pairs, needed to be finished and sent to the purchaser in Abuja before Azu could go to Warri that day. He was very excited that there had been electricity in his workshop since he had arrived that morning, so he could work with the machine. The day before, he had been unable to continue with the strenuous work because of an electricity cut. Sanding more than 70 pairs of shoes manually would have been a hell of a job, for which he had neither the time nor the desire. He celebrated the electricity and, even though he was cheerfully chatting with friends and customers who visited his workshop that morning, he used every second of it vigorously. At noon, while Azu was still working on sanding the shoes, the electricity supply was cut. "NEPA done kill me, oh! NEPA done finish me!" he shouted. ${ }^{3}$ Soon, neighboring shops turned on their generators, and the quiet environment around the workshop was quickly polluted with the deafening noise of at least six generators.

Azu did not own a generator. An electricity cut meant the end of any work he needed electricity for. He could not finish his work and had to postpone his trip to Warri for a day. In the meantime, he had to spend as many hours as possible in his workshop, waiting for power to come back on so he could finish the work. Irritated by the situation, he started complaining about Nigerian infrastructure in general—water, roads, and electricity—but having "no light" was his greatest frustration. It kept him from doing the work he intended to do, and needed to do, in order to make ends meet.

Azu exclaiming how NEPA had "killed" him that morning was about more than his not being able to finish the 70 pairs of shoes he had planned to send to Abuja later that day. It was not merely an expression of disappointment with the moment, but a groan coming from deeply rooted frustration with the dysfunctional Nigerian government. This example shows how duress 
impacts the decision-making of people living in it: Azu was being forced to adjust his original plans and short-term aspiration to finish the shoes in time and to continue with another incomeproviding assignment. But his exclamation "NEPA done kill me" was not about electricity alone. It was about the way in which he and many young people like him are severely limited, in their opportunities to progress and successfully achieve their aspirations in general, by the harshness of the life they are living in Nigeria.

Azu lives in Enugu. Here, war and violent conflict are relatively absent today. Terrorist activities, especially those by Boko Haram in the northeast of the country, are not a direct threat to the people in the southeast. They often claim they are completely unaffected by Boko Haram and the violence occurring in other parts of the country, and they even seem rather apathetic toward what is happening in Nigeria. However, the omnipresent "Othering" of northerners, including Fulani herders, in Enugu proves that the accounts of violence that reach them through the media do impact how they view the world and the people around them. Fear is unconsciously present, not because of direct threats of violence but because of the exposure to it through mediatized stories. It resonates with earlier conflict that took place in Enugu, most importantly the civil war that killed more than a million civilians in southeast Nigeria, the then secessionist state of Biafra. The sense of marginalization, the reason for the attempt to secede back then, is still palpable for so many of the Igbo living here today, including Azu (Ligtvoet and Oudenhuijsen 2018).

Azu's father was a very young soldier in the Biafran army during the Nigerian Civil War (1967-1970), in which he fought for the secessionist Igbo state of Biafra. At the end of the war, he returned home heroically. Azu proudly told me how his father carried his heavily injured brother home from the battlefield, walking a distance of more than 30 kilometers from Ohafia to 
Arochukwu. His father was also severely injured: a gunshot wound in his arm has impacted his life ever since, causing depression, unemployment, and arguably even the divorce of Azu's parents. The war, which ended 14 years before Azu was born, has therefore left a mark on his life and that of his family. In the recent Biafra protests in southeast Nigeria, ${ }^{4}$ Azu felt compelled to join the protests online and briefly associated himself with the IPOB, an organization pushing forward the agenda of the 1960s and striving toward an independent Biafra. But after some weeks of protests, few results were observable. Like many other young men, he could no longer afford to be involved in the protests actively, as he needed his time and money to work on making a profit, which would benefit him and his family (Ligtvoet and Oudenhuijsen 2018).

But to understand duress in the context of Azu's lifeworld, we should look at more than just the major forms of conflict that threaten (or have threatened) the country. The duress is primarily informed by the insecurity arising from everyday encounters with a failing and immensely corrupt political system. One clear example of this is the lack of reliable electricity and the consequential dependence on fuel-driven generators for almost everything, including the pumping of water and the sanding of designer shoes that generate income. This affects Nigerians in their everyday lives to the extent that most of them plan their days according to the availability of electricity: “Our daily routine is centered around when we have light and when we don't have light" (BattaBox 2016). Azu had to change his plans because of the lack of electricity. He did not finish the products in time, was unable to meet his other business appointment that day, and later even lost the ability to sell the 70 pairs of shoes when the purchaser lost interest because of the delay. Although Azu managed to sell all the shoes himself over the months that followed, the unreliability of electricity caused him to lose his initial business opportunity completely.

Electricity is just one example of the failing Nigerian system. Corruption is observable at 
every level of society and quite visible in the streets: almost all buildings bear a notice that reads, "This house is not for sale," informing people that they should not buy the property from fraudulent brokers. Accounts of government officials who have been accused of corruption and fraudulent practices fill the newspapers and social media feeds every day. Corruption is omnipresent, visible for everyone and internalized by all. It refers to the "whole range of social behaviour in which various forms of morally questionable deception enable the achievement of wealth, power, or prestige as well as much more mundane ambitions" (Smith 2007: 5). In their relations and communications with institutions, it is difficult for people to get anything done without "knowing someone" or paying informal fees to handling officers. Corruption and the state are transposable terms in Nigeria, yet in order for Nigerians to "achieve even their most mundane aspirations and reasonable goals" (14), they are forced to navigate through and participate in the system themselves. Nigerians are knowingly, yet grudgingly, living in and depending on what Daniel Jordan Smith (2007) calls “a culture of corruption.” Azu, always angry with corrupt government officials, once needed to pay 40,000 naira (about 238 dollars in 2014 to his study project's supervisor just for him to look at his final schoolwork and did so without questioning it, explaining to me that that is how things work "down here in Nigeria."

The corrupt core of the Nigerian state has nested deeply in society (Bayart 1993). This "informalization of politics, ... rule of law deficits and progressively weakening value systems" is what Akin Iwilade describes as crisis in the context of Nigeria (2013: 1057). Following Iwilade, crisis in Nigeria is thus not only about physical violence and conflict; even though this is an enduring problem in the country, and in some regions more than in others, the internalization or "normalization" of informal politics in everyday life is actually at the core of Nigeria's crisis-especially in areas where violent conflict is largely absent, as is the case in 
southeast Nigeria. This is the duress that young, upwardly mobile people like Azu live their lives in. In what follows, Azu's biography serves as an illustration of this duress and the ways in which it limits young people's aspirations and choices.

\section{Broken Home(s)}

Azu was born and bred in a small community close to Sapele in Delta State, where he lived with his parents, older brother, and two younger sisters. Both his father and mother hailed from a village in the Arochukwu local government area of Abia State. Azu refers to this village as his home, despite never having lived there. Life was not easy when Azu was growing up. His father's injuries during the civil war hindered his ability to work and provide for the family in the way that was expected of him. Whenever Azu spoke with me about his father, he would describe him as a lazy man who took no responsibility for his family. He was of the opinion that his father used his injuries as an excuse to not work. His father was a professional painter, contracted even by the local government, before and after the war. But the little work he did was not enough to provide for his family. After some time, Azu's father traveled back to the village in Abia State, where he is still living on his brother's compound. The rest of the family stayed in Delta State. Azu's mother did everything in her power to provide for the family, selling akamu (pap) and akara (bean cakes) on the streets. Unfortunately, her income was insufficient to send all her children to school, and the burden of feeding four children was too much for her to bear alone. When, in 1995, Azu's uncle in Ikom, close to the border with Cameroon, asked his sister, Azu's mother, if she could send one of her sons to help him with his company, she decided to send Azu, as he had been causing a lot of trouble at home. "Back in the days, I was very stubborn," Azu explained, "so my mum found it better that I should be the one to go .... I was really very 
stubborn. My stubbornness was that you can't look for my trouble and go free. I must fight it” (interview, December 2014).

His behavior was unmanageable for his mother, and she hoped he would get some discipline from living with her brother for a while. Azu had just finished primary school then and hoped that he could work in his uncle's company while his uncle would support him in secondary school, for which the costs involved in the 1990s were substantial, especially considering Azu's poor family background. ${ }^{5}$ Instead, his uncle placed him back in primary school for four years, and exploited and abused him at home and at the job site, where Azu was forced to carry heavy loads of wood. When Azu finished primary school for the second time, in 1999, his uncle refused to pay the costs involved in going to secondary school. It was around the turn of the millennium that Azu finally found his way back to Delta State, where he vowed to return to school and to take care of his mother.

Back in Delta State, Azu became an entrepreneur in order to get an education. At just 16 years old, he was determined to pay his own secondary school fees, which he knew his mother could not afford. He developed entrepreneurial skills because he had "no other choice" if he wanted to go to school. He refused to settle for a life on the street making money through criminal activities, the only other choice available, according to him, and the easy way out. Fortunately, his laundry business took off, and he was soon able to start school and contribute to his mother's small income to provide for the rest of his family. He hired friends to work for him, and he takes pride in the fact that "all of them went to school because of that shop." Meanwhile, Azu saw other age-mates from similar poverty-stricken backgrounds who "didn't like to work." “They just depend on their parents, I need this . .., I need that" (interview, 11 December 2014). They lost themselves in a world of criminality, drugs, and alcohol — all easily available. It was at 
this time that Azu rented his first apartment, defying the odds and officially disengaging himself from the poverty he grew up in. Nevertheless, he was still known as the boy from a poor and broken home - a status that would continue to haunt him as he was attempting to climb the social ladder in the 10 years that followed.

\section{"Nigerians Love Names"}

In 2007, Azu ended up in Enugu, where he still lives today. A pastor from Delta State was transferred to Enugu and asked Azu to join him and his family when they relocated. Azu was hired to do their laundry, and the pastor promised him that he would be able to continue his formal education in Enugu. But as the years went by, Azu found himself doing more and more chores in the house and having very few opportunities to educate himself. Although he speaks about the pastor and his family with much respect and they are still in close communication, Azu decided to leave the family after some time. He felt he was being treated like a houseboy, a status he believed he had already outgrown in the years before.

He rented his own apartment close to the university and set out on his journey as a fashion designer of shoes and bags, which, for a large part, he taught himself how to make. Not much later, he asked his younger sister to join him in Enugu to release some of his mother's burden. He sent her to school, and she helped him in and around the house. He also enrolled himself in school, studying civil engineering, which he can afford to do with the income his business generates — just as he did in secondary school. Azu loves his work as a designer, and his business continues to attract more and more customers, though he is having a hard time combining it with his formal education. However, he does not even think of quitting school. "Nigerians believe so much in certificate, not in skill," he said when I asked him why he 
continued to attend school despite the pressure it places on him (interview, 11 December 2014). He explained that, even if he becomes a successful designer, Nigerian investors and purchasers will still want to see a diploma — any diploma. He believes his skills alone will not bring him to the top. A certificate will break through certain boundaries, even though his formal education might not be explicitly relevant for the type of business he is involved in. He explained this in a WhatsApp conversation a year after I left Nigeria, when he told me that, because of an expensive sewing internship in Aba, he did not have money to go back to school:

Azu: I need to finish school. It wil help me package my hand work very well. Dat is Nigeria for u. Nigerians love names.

Me: Titles?

Azu: Yes. Dat is d right word. We don't joke wit dat. We $r$ incomplet witout dat. (WhatsApp chat, 3 March 2016, 8:02 p.m.)

\section{The Growth of a Fashion Label}

When I first met Azu in March 2014, he did not own a physical shop where he could sell the bags and shoes he had designed and made. He would walk around with some of his women's handbags and would always wear a pair of shoes he had made himself. It attracted attention, especially when he wore personally designed "native" attire that was always different from what one would normally see men wearing. He once sold all the handbags he was carrying to a group of surprised women on a short taxi ride within town. They could not believe he had made the bags himself and immediately decided to buy them all. From there, word-of-mouth advertising increased the number of customers. People called him for information, or they met up with him 
on campus. He continued to carry his designs around, hoping that people's amazement at a young man carrying around multiple "women's" bag designs would attract the attention of possible buyers. On his phone, he stored pictures of all his products, those he had already sold and those he still had in stock. When he attracted people's attention, he would let them browse through these photos and discuss prices for custom-made designs. A few months later, Azu rented a small container in the market area of his institute's campus. He painted it bright pink and created a roofed veranda in front of it. The container, which he referred to as his workshop, was where he spent all the time he was not in class. Here he worked on his designs and sold handmade products. Campus students often came to his shop to ask if he could repair their shoes. He was very reluctant and only occasionally agreed to do repairs, because he did not want to be seen as a shoemaker. Whenever he did agree, it was either because he knew the person very well or he desperately needed the money. He refused to be known as a shoemaker, as he believed he had outgrown that status, just as he had done when he rented his first home and when he left his pastor's compound because he felt treated like a houseboy.

When he opened his shop on campus, business changed. It was always busy at the market, and many students were curious about his designs. With clever communication (“I guarantee my slippers last longer than the ones you buy on the market") and his relatively cheap prices, he was able to sell quite a lot to students passing by. But most of his earnings came from custom designs: clutches or pairs of shoes to go with bridesmaid dresses were best sellers. Every now and then, a special request would come in. One day, Azu showed me an example of a fauxleather wallet he had made in bulk for a wedding, where they would be used as gifts for the guests. Not only his business changed; his marketing did as well. Compared with the previous strategy, his new strategy seemed relatively passive, even though he would still sometimes go 
home carrying handbags. Customers now located him. He was reachable not only through phone; people could also visit him in his shop. Occasionally, someone would show up at the workshop saying that a friend or family member that bought from Azu before had referred them to the shop. It was no longer necessary for Azu to go out to sell his products. His use of social media, which allowed him to reach customers beyond the campus and even beyond Enugu, was also important in this. His personal Facebook profile became a public display of shoes, bags, and slippers. The photos he used to show people on his phone when he would meet them face-to-face were now all visible online, always accompanied by a text including the name of his "fashion label" ("Made in Enugu") and his phone numbers.

Through his online network and the networks of his friends and his friends' friends, people from all over Nigeria and the world could now see his work and even negotiate prices from a distance. Unfortunately, even though social media seemingly open up the world, local constraints (e.g., the inability to travel, infrastructural problems) in the Global South (and especially in Nigeria) still make an actual non-digital (physical/material) exchange over large distances rather difficult for young entrepreneurs like Azu. Therefore, social media and these new connections, therefore, rather than bringing opportunities for the increasingly connected upwardly mobile youth, inform duress, as youth cannot chase after these opportunities freely given the limitations of local constraints. As such, social media can, in the context of these youth, be understood as yet another layer of duress, one of unattainable global aspirations.

\section{Not a Bed of Roses}

So far, Azu's story seems to have been one of ultimate success. From the poor second child in a broken family, he evolved into a young entrepreneur who can take care of himself and his 
family. The hardship he endured and the choices he made despite this hardship developed him into a relatively successful young man - a man who rents his own room where he lives with his sister and accommodates family members who stay in Enugu temporarily. After some months off on campus business, he was able to send his sister to culinary school. Although Azu's older brother culturally has the responsibility of taking care of his family members, he is not capable of or willing to do so. Because of this, Azu has taken up the responsibility of caring for his mother by regularly sending her money.

But overall, Azu is still suffering. After helping his family and paying his monthly bills, there is very little left for him to build up his own life further. He is no longer the marginalized boy he used to be when he was growing up, but his responsibilities toward his family will not allow him to prosper or to attain the middle-class status that he is seeking. He finds himself in a vicious circle of survival that he cannot seem to escape. And even though he is faring relatively well compared with many others from his background, he is stuck between his past and his future. One of the most poignant examples of the consequences of this is Azu's inability to marry Chisom, his fiancée. Her brother, who is acting on behalf of her deceased father, does not allow them to get married. When I asked him on WhatsApp about his wedding plans, two years after he proposed to Chisom, Azu told me: "Stil on iit ooooooo. D boy say NO. Her blood brother. D elder one who is standing as d father. Dat I don't hv money. So I really need money” (WhatsApp chat, 12 July $2016,7: 10$ p.m.). Azu is constrained not only by the failing and corrupt governance system that forced him, among other things, to eventually buy a generator for his business and to pay informal fees to graduate, but also by the expectations of a family whose demands are strenuous. And now, he even has to deal with his possible future family-in-law's expectations. On the last day of 2014, when I was visiting Azu's home village, we sat down on a bench 
in front of his late uncle's compound, and he began to explain to me why he had not planned to visit his village at Christmas this year: ${ }^{6}$

Definitely, I didn't have any plan of coming this year.... Economy yawa! Do you know what the word means: economy yawa? It means, economy is bad! That means, I don't have money. I did not come the way I used to. I usually come in December. ... I buy a lot of food stuff. Yes, that is what I need to do.... Right here, they don't have foodstuffs. ... And in the December period, those who sell, they increase it, because they know that people that stay outside the village have come and they believe that they have come with money. You can't tell anyone here that you don't have money. It's very difficult. They believe that life in the town is a bed of roses. And it's not.... They now see you, maybe you were once tiny, and then you now come back looking big. They say, "this guy is eating money. This guy is eating, oh!" So everyone that meets you—the eyes, they'll be looking at you: Is there anything you give me, is there any pocket money? ... I didn't want to come. I don't want to raise anybody's hope and then I go without fulfilling their hope. It's bad, you know. . . . Because if I don't have, they will not be able to understand; they will think maybe he has changed. Maybe there is a woman somewhere eating his money. That's not the truth. Just the fact that, this time, because of politics, no money anywhere. (informal conversation, 31 December 2014)

As a young, upwardly mobile Nigerian living in one of the country's urban centers, Azu is confronted every day by the high demands of family and friends and by many challenges, but he also encounters the brief windows of opportunity that the failing sociopolitical system 
presents him with. He lives in a state of uncertainty, in which there is no "absolute knowledge" and no way "to predict the outcome of events ... with assurance" (Reynolds Whyte 2009: 213). The uncertainty of informal politics that is present everywhere imposes enduring pressure on young people's aspirations, and they must continuously navigate an oppressive social landscape. In this state of duress, youth like Azu are confronted with "potential social futures" (JohnsonHanks 2002: 871) in a society in which they must make it themselves, since little can be expected from the governmental institutions and the conditions of rising youth unemployment in Nigeria (NBS 2018). In order to create their own prosperous future, they must navigate tactically within the limited space they have. As Michel de Certeau (1984: 37) writes, "[a tactic] takes advantage of 'opportunities' and depends on them" within the space for social navigation that is severely constrained by the malfunctioning state and the expectations of others due to these young people's acquired status. De Certeau (1984) speaks about "the art of the weak" as opposed to the strategies of the strong. The weak - in this case, the upwardly mobile youth who are, despite their "privileged" position in society, relatively powerless-must navigate through this confined space of duress, accepting "the chance offerings of the moment, and seize on the wing of possibilities that offer themselves at any moment" (quoted in Napolitano and Pratten 2007: 9).

In other words, upwardly mobile youth, rather than being able to truly, strategically pursue their aspirations, must seize the limited, transient opportunities they are offered to make a life for themselves. This does not mean that youth themselves do not make strategic decisions. However, these decisions, or tactics, are informed by the internalization of hardship and by the normalization of their constraints (i.e., duress). In this regard, Azu's determination to work tirelessly on sandpapering the order for slippers with his machine before the electricity was cut again, which he knew from experience would inevitably occur, can be understood as a metaphor 
of these tactics of everyday life: the reality of duress for upwardly mobile youth.

Azu's biography, as presented in this article, shows that in order to get to where he is today, he has tactically navigated constraining sociopolitical structures by making decisions that would eventually bring him some sort of prosperity and status-for example, his decision to educate himself, and his choice for entrepreneurship over crime (unlike the choice many of his peers made). However, this "prosperity" has also brought new constraints. Demands on him are high, and he needs to live up to his newly acquired status, feeling now financially responsible for his family — a feeling that arises not only from his care for family members but also from societal expectations of young successful men like him. The new expectations he faces impose new challenges, which should be understood in terms of duress in the context of upwardly mobile young people in southeast Nigeria.

\section{Conclusion}

Although Azu's story is not the story of all young people, I do believe-drawing on long-term ethnographical fieldwork among upwardly mobile youth in the region — that their realities of duress are similar. Young graduates and successful young entrepreneurs are dealing with high expectations because of their relative prosperity and privileged position in society. Azu's life shows that duress exists in the absence of direct physical conflict and is rooted in layers of enduring personal hardship —including his family's history and experiences with violence in the civil war - and shaped by the particular structure of the Nigerian state and by a certain acquired status in society. Despite his success, Azu is haunted by the internalization of his poor background and his confrontation with the unending challenges of making a living and being successful. Through his biography, I have been able to shed light on the meaning of living in 
duress for upwardly mobile youth in southeast Nigeria. I have shared some sociopolitical constraints and constraining social expectations that are for Azu, and many young people like him, part of everyday life and praxis. They are "obvious," but they have become an internal part of life. I argue that the normalization of this kind of hardship, one that is not about conflict or open violence, greatly limits the space in which upwardly mobile youth in Nigeria can move forward in pursuit of their aspirations.

\section{Acknowledgments}

I would like to thank Azu; his fiancée, Chisom; and his family for allowing me to be part of their lives and for trusting me with their stories. The research on which this article is based was funded by the Netherlands Organisation for Scientific Research (W01.70.600.001) within the project "Connecting in Times of Duress: Understanding Communication and Conflict in Middle Africa's Mobile Margins.”

Inge Ligtvoet is a $\mathrm{PhD}$ candidate at the Leiden University Institute for History. She is currently writing her dissertation on the ways in which upwardly mobile youth in southeast Nigeria navigate their lives in a context of experiencing long-term socioeconomic uncertainty and political insecurity. The dissertation has a particular focus on young people's use of information and communication technologies (ICTs), especially social media like Facebook and WhatsApp. Email: i.j.g.c.ligtvoet@hum.leidenuniv.nl

\section{References}

Apitzsch, Ursula, and Irini Siouti. 2007. "Biographical Analysis as an Interdisciplinary Research 
Perspective in the Field of Migration Studies." Unpublished manuscript. http://www.york.ac.uk/res/researchintegration/Integrative_Research_Methods/Apitzsch\% 20Biographical\%20Analysis\%20April\%202007.pdf.

Barman, Roderick. 2010. "Biography as History.” Journal of the Canadian Historical Association / Revue de La Societé Historique Du Canada 21 (2): 61-75. https://doi.org/10.7202/1003088ar.

BattaBox. 2016. "CRAZY: How Nigerians Struggle with Power-Cuts Every Day.” Video, 10:02. Posted 31 March. https://www.youtube.com/watch?v=sIhcI17GuWI.

Bayart, Jean-François. 1993. The State in Africa: The Politics of the Belly. London: Longman. Bouju, Jacky, and Mirjam de Bruijn. 2014. Ordinary Violence and Social Change in Africa. Leiden: Brill.

Buitelaar, Marjo. 2014. “'Discovering a Different Me': Discursive Positioning in Life Story Telling over Time.” Women's Studies International Forum 43 (3): 30-37.

Davies, James. 2010. "Introduction. Emotions in the Field.” In Davies and Spencer 2010: 1-34.

Davies, James, and Dimitrina Spencer, eds. 2010. Emotions in the Field: The Psychology and Anthropology of Fieldwork Experience. Stanford, CA: Stanford University Press.

de Certeau, Michel. 1984. The Practice of Everyday Life. Berkeley: University of California Press.

FRN (Federal Republic of Nigeria). 1998. National Policy on Education. 3rd ed. Yaba: Nigerian Educational Research and Development Council Press.

Imam, Hauwa. 2012. "Educational Policy in Nigeria from the Colonial Era to the Postindependence Period." Italian Journal of Sociology of Education 1: 181-204.

Iwilade, Akin. 2013. "Crisis as Opportunity: Youth, Social Media and the Renegotiation of 
Power in Africa." Journal of Youth Studies 16 (8): 1054-1068.

https://doi.org/10.1080/13676261.2013.772572.

Jackson, Michael. 1998. Minima Ethnographica: Intersubjectivity and the Anthropological Project. Chicago: University of Chicago Press.

Jackson, Michael. 2010. "From Anxiety to Method in Anthropological Fieldwork: An Appraisal of George Devereux’s Enduring Ideas.” In Davies and Spencer 2010: 35-54.

Johnson-Hanks, Jennifer. 2002. “On the Limits of Life Stages in Ethnography: Toward a Theory of Vital Conjunctures.” American Anthropologist 104 (3): 865-880. https://doi.org/10.1525/aa.2002.104.3.865.

Leavitt, John. 1996. "Meaning and Feeling in the Anthropology of Emotions.” American Ethnologist 23 (3): 514-39. https://doi.org/10.1525/ae.1996.23.3.02a00040.

Ligtvoet, Inge, and Loes Oudenhuijsen. 2018. "Jeunesse Rebelle? Médias sociaux, leadership charismatique, et jeunes 'radicalisés' lors des manifestations de 2015 au Biafra" [Rebel youth? Social media, charismatic leadership, and 'radicalized' youth at 2015 Biafra events]. In Biographies de la radicalisation: Des messages cachés du changement social [Biographies of radicalization: Messages of social change], ed. Mirjam de Bruijn, 157179. Bamenda, Cameroon: Langaa RPCIG.

Napolitano, Valentina, and David Pratten. 2007. "Michel de Certeau: Ethnography and the Challenge of Plurality." Social Anthropology 15 (1): 1-12. https://doi.org/10.1111/j.1469-8676.2007.00005.x.

NBS (National Bureau of Statistics). 2018. "Key Statistics > Unemployment.” Accessed 12 August. http://www.nigerianstat.gov.ng.

Reynolds Whyte, Susan. 2009. "Epilogue.” In Dealing with Uncertainty in Contemporary 
African Lives, ed. Liv Haram and C. Bawa Yamba, 213-216. Stockholm: Nordiska Afrikainstitutet.

Rosenthal, Gabriele. 2004. “Biographical Research.” In Qualitative Research Practice, ed. Clive Seale, Giampietro Gobo, Jaber F. Gubrium, and David Silverman, 48-64. London: Sage. Smith, Daniel Jordan. 2007. A Culture of Corruption. Princeton, NJ: Princeton University Press. Svašek, Maruška, and Zlatko Skrbiš. 2007. "Passions and Powers: Emotions and Globalisation." Identities: Global Studies in Culture and Power 14 (4): 367-383. https://doi.org/10.1080/10702890701578415.

\section{Notes}

\footnotetext{
${ }^{1}$ Names in this article have been anonymized.

${ }^{2}$ Azu's biography presented here is part of a body of biographies of upwardly mobile youth in southeast Nigeria that are the basis of my $\mathrm{PhD}$ dissertation.

${ }^{3}$ The National Electric Power Authority (NEPA) was the public supplier and distributor of electricity in Nigeria since 1972, before President Goodluck Jonathan's administration privatized the market for electricity in 2013. Despite the fact that NEPA ceased to exist in 2005, when the authority's name was changed to the Power Holding Company of Nigeria, Nigerians still refer to NEPA when speaking about electricity. These days, the abbreviation is jokingly referred to as "Never Expect Power Always."

${ }^{4}$ Since 2015, there have been demonstrations globally, but particularly in southeast Nigeria, in which protestors demand the sovereignty of the Republic of Biafra.

${ }^{5}$ Nowadays, primary and secondary education in Nigeria is free, although significant costs for uniforms and utensils are involved. However, in the 1990s, before a revised edition of the
} 
National Policy on Education (FRN 1998) was implemented in the 1999 Constitution, free universal basic education was not the standard (Imam 2012).

${ }^{6}$ During the December period, many Igbo find their way back home (the village where they hail from) to celebrate Christmas and local festivals with their relatives and friends. At my request, we traveled to his village together during that time in 2014 so that I could get an idea of where he comes from and have a chance to meet with his father. Azu, however, did not want to go that year, because he was not feeling up to the challenge financially. He did not tell me about this before we traveled but did after we had visited some of his family members who all asked him for something. 